\author{
I. G. HAYDUCHOK (Lviv, Ukraine)
}

\title{
INNOVATIVE APPROACHES TO PHARMACOTHERAPY OF SYSTEMIC AUTOIMMUNE DISEASES IN THE CONDITIONS OF THE COVID-19 PANDEMIC
}

\author{
Lviv Medical Institute<pharm_law@ukr.net>
}

Introduction. In the current context of the spread of the coronavirus pandemic, the role of pharmacotherapy in the maintenance of immunopathological syndromes among patients with systemic diseases and patients with dual health disorders is growing. The need to adjust the pharmacotherapy regimens of systemic autoimmune diseases arises when addressing issues of quality, economic and physical availability of drugs in accordance with wholesale and retail prices. In continuation of the research, the aim of the work was to study and implement innovative approaches in the pharmacotherapy of systemic autoimmune diseases by content analysis on the example of antiviral drugs for international nonproprietary name (INN) Acyclovir. Materials and methods. The information base of the study consisted of scientific works of foreign and domestic scientists on the topic of the article. The review of scientific sources of literature was carried out taking into account the recommendations of the Cochrane Society for PICO. The names of drugs were systematized by INN, trade names, the number of drugs, dosage forms. For the content analysis, the method of drug selection developed by the Department of Medical and Pharmaceutical Law, General and Clinical Pharmacy of the Kharkiv Medical Academy of Postgraduate Education was used, which included seven criteria. Discussion. At the first stage of the study, a marketing analysis of the range of drugs for INN Acyclovir was performed. Medicines were selected, which according to the State Register of Medicines of Ukraine as of November 2020 were registered and allowed for circulation in health care facilities. After summarizing the processed data, a marketing list of drugs was compiled under the ATC code J05AB01 in accordance with the INN Acyclovir, which has 36 names of drugs. During the study, a discrete variation series of drug distribution was compiled, which indicates that the studied quantitative indicator of drug manufacturers fluctuates within the first group with the highest frequency $\left(f_{i}=8\right)$. A graphic discrete variation in the form of a distribution polygon was created. Conclusions. Innovative approaches to the pharmacotherapy of systemic autoimmune diseases are the use of content analysis as an additional method in the study of pharmacotherapy of drugs. The study is based on the formalized method of qualitative and quantitative analysis of documents, which allows you to get a detailed picture of the selected clinical and pharmacological group of drugs - drugs by INN Aciclovir PBX code J05AB01. The analysis allows obtaining a complete description of the range and manufacturers of drugs approved for use.

Key words: evidence-based medicine; forensic pharmacy; pharmacotherapy; systemic autoimmune diseases; drugs, content analysis.

Introduction. In the current context of the spread of the coronavirus pandemic, the role of pharmacotherapy in the maintenance of immunopathological syndromes among patients with systemic diseases and patients with dual health disorders is growing. Despite numerous publications on COVID-19, currently conceptual thinking of the problem is only in its infancy. Pharmacotherapy of patients with systemic connective tissue diseases during the COVID-19 pandemic is one of the pressing issues. Further analysis of COVID-19 in patients with systemic autoimmune diseases is important $[3,4,10,23]$.

Among the systemic autoimmune diseases are systemic lupus erythematosus, systemic vasculitis, psoriasis, rheumatoid arthritis. Understanding immunopatholo- 
gical syndromes among patients is important for making a correct diagnosis and ensuring proper pharmacotherapy. The introduction of innovative approaches in pharmacotherapy regimens when prescribing drugs of different clinical-pharmacological, classification-legal, nomenclature-legal groups is timely in the conditions of the COVID-19 pandemic. Thus, during the pharmacotherapy of systemic autoimmune diseases, the use of innovative research methods influences the justification of the choice and replacement of drugs to avoid reducing their effectiveness, preventing side effects, taking into account contraindications [2, 5, 7, 18, 27, 28].

Separately, the need to adjust the pharmacotherapy regimens of systemic autoimmune diseases arises when addressing issues of quality, economic and physical availability of drugs in accordance with wholesale and retail prices. It is known that drugs for privileged categories of patients with systemic autoimmune diseases are purchased at the expense of the budget and are subject to release on a free basis or $50 \%$ discount from their price. Today it is important to use modern, effective and safe drugs for pharmacotherapy of systemic autoimmune diseases, which are selected on the principles of evidence-based medicine, forensic pharmacy, evidence-based pharmacy, medical and pharmaceutical law $[16,17,21,22]$.

Therefore, the introduction of innovative approaches in the pharmacotherapy of systemic autoimmune diseases is a necessary and socially oriented scientific task. The social focus of pharmacotherapy of systemic autoimmune diseases should be focused directly on patients. At the same time, a fair balance between the supply and demand of drugs must be implemented. Demand for drugs is formed by patients with systemic autoimmune diseases. The proposal is formed by domestic and foreign drug manufacturers. A fair balance cannot be achieved if patients do not receive the pharmacotherapy prescribed by the doctor on time and on time [12, 25].

Earlier, the experience of Finland and Poland in the organization of the health care system for pharmacotherapy of privileged categories of citizens was described $[13,26]$. The use of pharmacoeconomic approaches in pharmacotherapy of systemic vasculitis combined with cryoglobulinemic syndrome using antiviral drugs was justified in the study [14].

In continuation of research, the aim of the work was to study and implement innovative approaches in pharmacotherapy of systemic autoimmune diseases through content analysis on the example of antiviral drugs at international nonproprietary name (INN) Acyclovir in healthcare facilities (hospitals, clinics, pharmacies).

Materials and methods. The information base of the study consisted of scientific works of foreign and domestic scientists on the topic of the article. The review of scientific sources of literature was carried out taking into account the recommendations of the Cochrane Society for PICO: P (population) - the population suffering from systemic autoimmune diseases; I (intervention) - pharmacotherapy, effective, safe, affordable drugs; C (comparator) - research technology; O (outcomes) - research results $[9,11,15,20,24]$.

The names of drugs were systematized by INN, trade names, the number of drugs, dosage forms. The analysis on the basis of production was performed with the determination of the share of domestic and foreign drugs, by individual countries, manufacturing companies. Drugs clinical and pharmacological groups for pharmacotherapy of systemic autoimmune diseases with diagnostic code of the ATC - Classification (ATC) ATC code J05AB01 was selected. The objects of the study were 36 drugs by the INN Aciclovir ATC-code J05AB01, which are registered in the State Register of drugs of Ukraine as of November 2020 [1, 14].

To conduct the content analysis, the method of drug selection developed by the Department of Medical and Pharmaceutical Law, General and Clinical Pharmacy of the Kharkiv Medical Academy of Postgraduate Education (Head of the Department Prof. Viktoriya Shapovalova) was used, which included seven criteria (Fig. 1). 


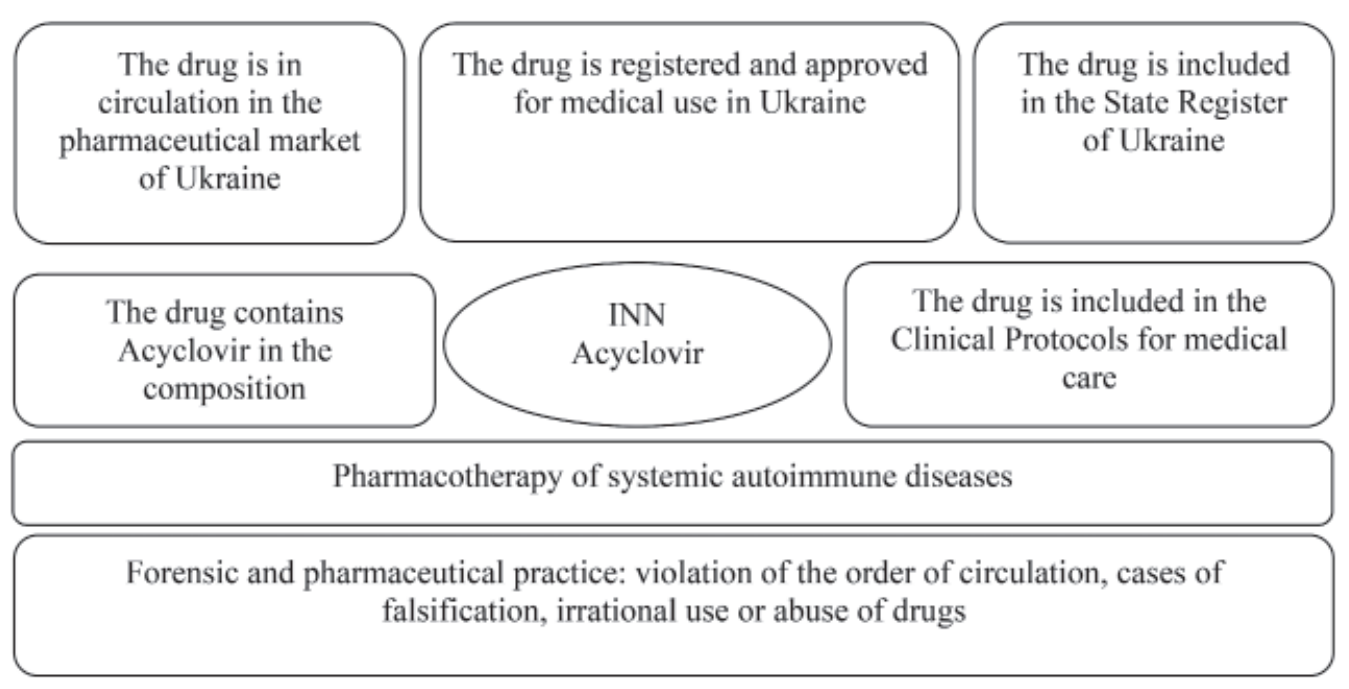

Fig. 1. Criteria for selection of drugs with international nonproprietary name Acyclovir for research $[6,8]$

Content analysis was performed by grouping drugs by indicator relative to the drug manufacturer. The grouping indicator was understood as the country of the producer of drugs with INN Acyclovir, the products of which are registered in Ukraine. Content analysis of drugs was performed by manufacturers by grouping them using the Sturgess formula and subsequent construction of discrete series of variations and the distribution polygon. The Sturgess formula used to calculate the number of groups of drugs is as follows:

$$
n=1+3.322 \lg N \text {, }
$$

where $n-$ is the number of variations; $N$ - is the number of drugs.

The boundaries of the step of certain groups of drugs were determined by the formula:

$$
h=\frac{X \max -X \min }{n},
$$

where $h$-is the magnitude of the step of the group; $X_{\max }$ - the maximum number of manufacturers; $X_{\min }$ - the minimum value of the number of manufacturers.

As additional research methods, normative-legal, documentary, clinical-pharmacological, marketing, tabular, forensic-pharmaceutical and graphic were used. Microsoft Excel 2010 was used to process the results and determine the consistency between the studied parameters (descriptive characteristics: minimum and maximum value, average value).

The research of the article is a fragment of research works of Lviv Medical Institute on the topic "Improvement of the drug circulation system during pharmacotherapy on the basis of evidence-based pharmacy and forensic pharmacy, organization, technology, biopharmacy and pharmaceutical law" (state registration number 0120U105348, terms 2021-2026), Kharkiv Medical Academy of Postgraduate Education on "Improving the organizational and legal procedure for providing patients with drugs from the standpoint of forensic pharmacy, organization and management of pharmacy" (state registration number 0116U003137, terms 2016-2020) and "Pharmaceutical and medical law: integrated approaches to the system of drug circulation from the standpoint of forensic pharmacy and organization of pharmaceutical business" (state registration number D/21U000031, terms 2021-2026) $[15,16,19]$. 
Research results and discussion. Americans are rightly considered inventors and leaders of content analysis, but in fact content analysis was first used in 1640 in Sweden. In general, it can be noted that nowadays no documentary research can be carried out without the use of the method of content analysis. This method continues its development and combines the best features of qualitative and quantitative methods with the advantages of formalized, quantified analysis. Based on the content analysis, our task was to list the qualitative and quantitative indicators of textual information on the use of drugs in pharmacotherapy regimens, as well as to quantify the data obtained. According to the clinical and pharmacological group for pharmacotherapy of systemic autoimmune diseases were selected drugs that have the diagnostic code ATC - Classification (ATC): J05 Antiviral agents for systemic use; J05A Direct acting antivirals; J05AB01 antiviral agents for systemic use according to INN Acyclovir [1].

At the first stage of the study, a marketing analysis of the range of drugs by INN Acyclovir was performed. During the marketing analysis of the range of drugs on the national market, an information array of marketing information about drugs was initially formed using the content analysis of official reference publications. Medicines were selected, which according to the State Register of Medicines of Ukraine as of October 2020 were registered and allowed for circulation in healthcare institutions. After summarizing the processed data, a marketing list of drugs of the ATC-code J05AB01 according to the INN Acyclovir was compiled, which includes 36 names of drugs (Table 1$)$.

Table 1. Marketing analysis of drugs of the ATC-code J05AB01 according to International nonproprietary name Acyclovir for pharmacotherapy of patients with systemic autoimmune diseases

\begin{tabular}{|c|c|}
\hline Trade name / Manufacturer & $\begin{array}{c}\text { Dosage form, strength, amount } \\
\text { per unit }\end{array}$ \\
\hline "Zoviraks / Glaxo Wellcome SA, Great Britain & Cream $5 \%$ \\
\hline Aciclovir / Belupo, Croatia & Cream $5 \%$ \\
\hline Agerp / Sperko Ukraine, Ukraine & Cream $5 \%$ \\
\hline Atsik / Salutas Pharma GmbH, Germany & Cream $5 \%$ \\
\hline Zoviraks duo / Glaxo Wellcome SA, Great Britain & Cream $5 \%$ \\
\hline Lipster / JSC “Farmak", Ukraine & Cream $5 \%$ \\
\hline Aciclovir / Pharmaceutical Factory LTD, Ukraine & Ungventum $2,5 \%$ \\
\hline Herpevir / PJSC “Kyivmedpreparat”, Ukraine & Tablets $200 \mathrm{mg}$ \\
\hline Medovir / Medokemi LTD, Cyprus & Tablets $400 \mathrm{mg}$ \\
\hline Medovir / Medokemi LTD, Cyprus & Tablets $800 \mathrm{mg}$ \\
\hline $\begin{array}{l}\text { Aciclovir-Darnitsa, PJSC “Pharmaceutical firm” Darnitsa “, } \\
\text { Ukraine }\end{array}$ & Tablets $200 \mathrm{mg}$ \\
\hline Aciclovir 200 Stada, Herds Arnzeimittel AG, Germany & Tablets $200 \mathrm{mg}$ \\
\hline Atsik / Salutas Pharma GmbH, Germany & Tablets $200 \mathrm{mg}$ \\
\hline Aciclovir-Astrafarm, LLC “Astrafarm”, Ukraine & Tablets $200 \mathrm{mg}$ \\
\hline Zoviraks / Glaxo Wellcome SA, Spain & Tablets $200 \mathrm{mg}$ \\
\hline Viroleks / KRKA, Novo mesto, Slovenia & Tablets $200 \mathrm{mg}$ \\
\hline $\begin{array}{l}\text { Aciclovir / Lekhim-Kharkiv Private Joint-Stock Company, } \\
\text { Ukraine }\end{array}$ & Tablets $200 \mathrm{mg}$ \\
\hline Aciclovir 200 Stada / Herds Arnzeimittel AG, Germany & Tablets $400 \mathrm{mg}$ \\
\hline Atsik / Salutas Pharma GmbH, Germany & Tablets $400 \mathrm{mg}$ \\
\hline Aciclovir 200 Stada / Stada Herds Arnzeimittel AG, Germany & Tablets $800 \mathrm{mg}$ \\
\hline Aciclovir-Farmak / JSC “Farmak", Ukraine & Tablets $200 \mathrm{mg}$ \\
\hline Herpevir / PJSC “Kyivmedpreparat”, Ukraine & Tablets $200 \mathrm{mg}$ \\
\hline Herpevir / PJSC “Kyivmedpreparat”, Ukraine & Tablets $200 \mathrm{mg}$ \\
\hline
\end{tabular}




\begin{tabular}{lc}
\hline \multicolumn{1}{c|}{ Trade name / Manufacturer } & $\begin{array}{c}\text { Dosage form, strength, amount } \\
\text { per unit }\end{array}$ \\
\hline \hline Lipster / JSC "Farmak", Ukraine & Tablets $400 \mathrm{mg}$ \\
Lipster / JSC "Farmak", Ukraine & Tablets 200 mg \\
Lipster / JSC "Farmak", Ukraine & Tablets $800 \mathrm{mg}$ \\
Geviran / Pharmaceutical plant "Polpharma" SA, Poland & Tablets 200 mg \\
Geviran / Pharmaceutical plant " Polpharma " SA, Poland & Tablets 400 mg \\
Geviran / Pharmaceutical plant " Polpharma " SA, Poland & Tablets $800 \mathrm{mg}$ \\
Aciclovir - Belmed / Belmedpreparaty, Republic of Belarus & Powder for infusion 250 mg \\
Aciclovir - Belmed / Belmedpreparaty, Republic of Belarus & Powder for infusion 500 mg \\
Zoviraks / Glaxo Wellcome SA, Italy & Powder for infusion 250 mg \\
Viroleks / KRKA, dd, Novo mesto, Slovenia & Powder for infusion 250 mg \\
Herpevir / PJSC "Kyivmedpreparat", Ukraine & Powder for infusion 250 mg \\
Medovir / Medocemi LTD, Cyprus & Powder for infusion 250 mg \\
Medovir / Medocemi LTD, Cyprus & Powder for infusion 500 mg \\
\hline
\end{tabular}

To conduct the next stage of content analysis to study the balance of supply and demand, the studied drugs were distributed by manufacturers and the number of drugs in circulation on the pharmaceutical market of Ukraine (Table 2).

Table 2. Primary data for content analysis from the list of drug manufacturers according to International nonproprietary name Acyclovir ATC-code J05AB01 for pharmacotherapy of patients with systemic autoimmune diseases

\begin{tabular}{lc}
\hline \multicolumn{1}{c}{ Manufacturer } & Quantity of drugs \\
\hline \hline Belupo, Croatia & 1 \\
Glaxo Wellcome SA, Spain & 1 \\
Glaxo Wellcome SA, Italy & 1 \\
PJSC “Pharmaceutical firm” Darnitsa “, Ukraine & 1 \\
Lekhim-Kharkiv Private Joint-Stock Company, Ukraine & 1 \\
Sperko Ukraine, Ukraine & 1 \\
LLC “Astrafarm”, Ukraine & 1 \\
Pharmaceutical Factory LTD, Ukraine & 1 \\
Glaxo Wellcome SA, Great Britain & 2 \\
KRKA, Novo mesto, Slovenia & 2 \\
Belmedpreparaty, Republic of Belarus & 2 \\
Salutas Pharma GmbH, Germany & 3 \\
Stada Herds Arnzeimittel AG, Germany & 3 \\
Pharmaceutical plant “ Polpharma “ SA, Poland & 3 \\
Medokemi LTD, Cyprus & 4 \\
PJSC “Kyivmedpreparat”, Ukraine & 4 \\
JSC “Farmak”, Ukraine & 5 \\
Total & 36 \\
\hline
\end{tabular}

There are drugs from 17 manufacturers (Table 2) in circulation. The number of names of drugs from these manufacturers is from one to five items. When calculating the number of drugs produced by different pharmaceutical manufacturers, the number of groups (five groups) and the step of the group (0.8-1) were determined (Table 3).

According to the calculations, the studied drugs with acyclovir were divided into 5 groups by 17 manufacturers (Tables 4-8).

Manufacturers and the number of names of drugs with acyclovir, included in the first group are given in Table 4. 
Table 3. Determination of the limit of the group step in the generalization of data by drug manufacturers according to International nonproprietary name Acyclovir ATC-code J05AB01 for pharmacotherapy of patients with systemic autoimmune diseases

\begin{tabular}{l|c|c}
\hline \multicolumn{1}{c|}{ Group No. } & The initial value of the step & The final value of the step \\
\hline \hline $1^{\text {st }}$ group & 1 & 1 \\
$2^{\text {nd }}$ group & 2 & 2 \\
$3^{\text {rd }}$ group & 3 & 3 \\
$4^{\text {th }}$ group & 4 & 4 \\
$5^{\text {th }}$ group & 5 & 5 \\
\hline
\end{tabular}

Table 4. Manufacturers and number of names of the first group of drugs according to International nonproprietary name Acyclovir ATC-code J05AB01 for pharmacotherapy of patients with systemic autoimmune diseases

\begin{tabular}{l|c}
\hline \multicolumn{1}{c|}{ Manufacturer } & Number of items \\
\hline \hline Belupo, Croatia & 1 \\
Glaxo Wellcome SA, Spain & 1 \\
Glaxo Wellcome SA, Italy & 1 \\
PJSC "Pharmaceutical firm” Darnitsa “, Ukraine & 1 \\
Lekhim-Kharkiv Private Joint-Stock Company, Ukraine & 1 \\
Sperko Ukraine, Ukraine & 1 \\
LLC “Astrafarm”, Ukraine & 1 \\
Pharmaceutical Factory LTD, Ukraine & 1 \\
Total & 8 \\
\hline
\end{tabular}

Based on the data obtained in Tables 4-8, we can analyze the pharmaceutical market for drug manufacturers whose products are in demand in the pharmacotherapy of systemic autoimmune diseases. The first group included five domestic manufacturers and three foreign manufacturers, each of which provides pharmacotherapy with only one drug. In the range of the second group there are three foreign manufacturers of Acyclovir, which have approximately equal shares (about 33\%) to provide pharmacotherapy (Table 5).

Table 5. Manufacturer and number of names of the second group of drugs according to INN Acyclovir ATC-code J05AB01 for pharmacotherapy of patients with systemic autoimmune diseases

\begin{tabular}{lc}
\hline \multicolumn{1}{c|}{ Manufacturer } & Number of items \\
\hline \hline Glaxo Wellcome SA, Great Britain & 2 \\
KRKA, Novo mesto, Slovenia & 2 \\
Belmedpreparaty, Republic of Belarus & 2 \\
Total & 6 \\
\hline
\end{tabular}

Manufacturers and the number of names of drugs with acyclovir, included in the third group are presented in table. 6 .

Table 6. Manufacturers and number of names of the third group of drugs according to INN Acyclovir ATC-code J05AB01 for pharmacotherapy of patients with systemic autoimmune diseases

\begin{tabular}{lc}
\hline \multicolumn{1}{c|}{ Manufacturer } & Number of items \\
\hline \hline Salutas Pharma GmbH, Germany & 3 \\
Stada Herds Arnzeimittel AG, Germany & 3 \\
Pharmaceutical plant “ Polpharma " SA, Poland & 3 \\
Total & 9 \\
\hline
\end{tabular}


The offer in the third group is shared by three foreign producers $(66 \%$ - Germany; $34 \%$ - Poland). In general, the number of names of drugs in the third group is more than $50 \%$ compared to the second group. Based on this, we can assume that the balance of "demand-supply" in the third group is close to what is desired for patients.

Manufacturers and the number of names of drugs with acyclovir, included in the fourth group are presented in table. 7 .

Table 7. Manufacturers and number of names of the fourth group of drugs according to INN Acyclovir ATC-code J05AB01 for pharmacotherapy of patients with systemic autoimmune diseases

\begin{tabular}{lc}
\hline \multicolumn{1}{c|}{ Manufacturer } & Number of items \\
\hline \hline Medokemi LTD, Cyprus & 4 \\
PJSC “Kyivmedpreparat”, Ukraine & 4 \\
Total & 8 \\
\hline
\end{tabular}

Based on the data in Table 7, the fourth group included two producers from Cyprus (50\% share) and Ukraine (50\% share). The balance of "supply and demand" in the fourth group is on a par with the first group.

Manufacturers and the number of names of drugs with acyclovir, included in the fifth group are presented in Table 8 .

Table 8. Manufacturers and number of names of the fifth group of drugs according to INN Acyclovir ATC-code J05AB01 for pharmacotherapy of patients with systemic autoimmune diseases

\begin{tabular}{lc}
\hline \multicolumn{1}{c|}{ Manufacturer } & Number of items \\
\hline \hline JSC "Farmak", Ukraine & 5 \\
Total & 5 \\
\hline
\end{tabular}

In the fifth group there is one domestic drug manufacturer with Acyclovir - JSC "Farmak", which has five names of drugs. It can be assumed that this manufacturer provides pharmacotherapy of systemic autoimmune diseases with affordable drugs with acyclovir and its products are in greater demand among patients.

Based on the content analysis of drugs by manufacturers and quantitative indicators, statistical processing of research results was performed by constructing discrete variation series and polygons of distribution of the obtained data. The discrete variation series is given in Table 9.

Table 9. Discrete variation series of drugs according to International nonproprietary name of the Acyclovir ATC-code J05AB01 for pharmacotherapy of patients with systemic autoimmune diseases

\begin{tabular}{c|c|c}
\hline Group No. & Group range & Frequency, $f_{\mathrm{i}}$ \\
\hline \hline 1 & 1 & 8 \\
2 & 2 & 3 \\
3 & 3 & 3 \\
4 & 4 & 2 \\
5 & 5 & 1 \\
\hline
\end{tabular}

The obtained discrete variation series of drug distribution indicates that the studied quantitative indicator of drug manufacturers varies within the first group with the highest frequency $\left(f_{\mathrm{i}}=8\right)$. Graphically discrete variation series of the studied drugs is presented in Fig. 2 in the form of a distribution polygon. 


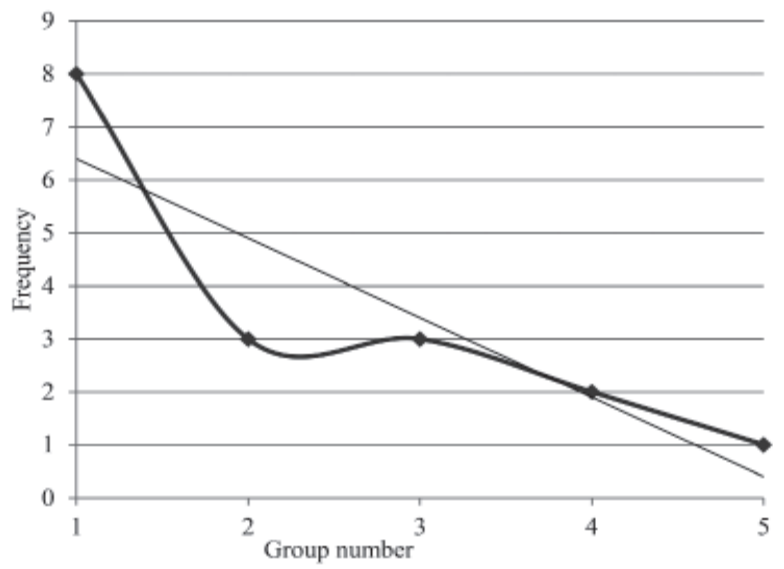

Fig. 2. Discrete variation series of drugs according to international nonproprietary name Acyclovir ATC-code J05AB01 for pharmacotherapy of patients with systemic autoimmune diseases: $\multimap-$ freguency; —- linear freguency; $y=-1.5 \mathrm{x}+7.9: \mathrm{R} 2=0.77$

In the first group most producers (8), the share of Ukraine - more than $60 \%$; Croatia, Spain, Italy - the same, about $13 \%$. However, these eight manufacturers supply one drug, which cannot meet the full needs of patients with systemic autoimmune diseases. Thus, the results of the study indicate that there is no proper balance between supply and demand of drugs according to the INN of the Aciclovir for the pharmacotherapy of systemic autoimmune diseases.

Conclusions. An innovative feature of the study is that the content analysis is based on the creation of a media-neutral framework for the classification of efficacy descriptions. Innovative approaches to pharmacotherapy of systemic autoimmune diseases are the use of content analysis as an additional method in the study of pharmacotherapy of drugs. The study is based on the formalized method of qualitative and quantitative analysis of documents, which allows obtaining a detailed view of the selected clinical and pharmacological group of drugs - INN Acyclovir ATC code J05AB01. The analysis allows obtaining a complete description of the range and manufacturers of drugs approved for use. Content analysis is a widely used innovative method of analysis of pharmacotherapy schemes for systemic connective tissue diseases. Further studies needed in order to propose patient-oriented approach for proper pharmaceutical therapy for pharmacotherapy of patients with systemic autoimmune diseases.

Gratitude. Author thanks the administration, doctors and nurses of the Lviv Medical Institute LLC, Kharkiv Medical Academy of Postgraduate Education, State Institution «Kundiiev Institute of Occupational Health of the National Academy of Medical Sciences of Ukraine», Danylo Halytsky Lviv National Medical University, for their help and support when working with clinical protocols and drugs during a qualitative study.

Conflict of interests. There is no conflict of interest to disclose for each author.

$$
\mathrm{R} \text { e f e re n c e s }
$$

1. АТС-класифікація.-Компендіум оn-line.http://www.compendium.com.ua/atc

2. Гайдучок I. Г., Шаповалова В. О., Шаповалов В. В., Шаповалов В. В. Режим контролю лікарських засобів для фармакотерапії ревматоїдного артриту. Інформаційний лист про нововведення Укрмедпатентінформ МO3 України. К.: Укрмедпатентінформ МОЗ України. - 2021. - № 36-2021. - 7 с.
1. ATS-klasifikaciya. - Kompendium on-line. - http://www.compendium.com.ua/atc

2. GajduchokI. G., Shapovalova V.O., Shapovalov V. V., Shapovalov V. V. Rezhim kontrolyu likars'kih zasobiv dlya farmakoterapiï revmatoïdnogo artritu. Informacijnij list pro novovvedennya Ukrmedpatentinform MOZ Ukraïni. - K.: Ukrmedpatentinform MOZ Ukraïni. - 2021. - № 362021. -7 p. 
3. Гайдучок I. Г., Шаповалова В. О., Шаповалов В. В., Шаповалов В. В. Режим контролю антибактеріальних лікарських засобів для фармакотерапії коронавірусної хвороби (COVID-19) у пацієнтів 3 дуальними розладами. Інформаційний лист про нововведення Укрмедпатентінформ МO3 України. Київ: Укрмедпатентінформ МОЗ України. -2020 . - № 230-2020. - 6 c.

4. Гайдучок І. Г., Шаповалова В. О., Шаповалов В. В., Шаповалов В. В. Режим контролю лікарських засобів для фармакотерапії коронавірусної хвороби (COVID-19) у хворих на системні захворювання. Інформаційний лист про нововведення Укрмедпатентінформ МO3 України. - К.: Укрмедпатентінформ МО3 України. - 2020. - № 225-2020. - 6 с.

5. Гайдучок I. Г., Шаповалова В. О., Шаповалов (мол.) В. В., Шаповалов В. В. Режим контролю лікарських засобів для фармакотерапії васкуліту Шенлейн Геноха: Інформаційний лист про нововведення Укрмедпатентінформ МO3 України. - К.: Укрмедпатентінформ МОЗ України, 2021. - № 64-2021. - 7 с.

6. Гудзенко А. О., Осиниева А. О., Шаповалова В. О. та ін. Контент-аналіз обігу спиртових лікарських засобів за лікарською формою та реєстраційними посвідченнями. - Авт. право 79473 (Україна). - Заявка № 80713 від 24.05.2018. Опубл. 01.06.2018.

7. Ємченко Я. О., Іщчейкін К. С., Кайдашев I. П. Аналіз захворюваності та поширеності на псоріаз в Україні та в Полтавській області // Вісн. ВДНЗУ «Українська медична стоматологічна академія». - 2014. - Т. 14, Вип. 3. - С. 72-76.

8. Шаповалова В. О., Зброжек С. I., Шаповалов (мол.) В. В., Шаповалов В. В. Контент-аналіз аптечних закладів України, де виготовляють екстемпоральні лікарські засоби // Здоров'я суспільства. 2017. - T.6, № 3-4. - C. 77-83. - DOI: 10.22141/2306-2436.6.3.2017.123498
3. GajduchokI. G., Shapovalova V. O., Shapovalov $V$. V., Shapovalov $V$. V. Rezhim kontrolyu antibakterial'nih likars'kih zasobiv dlya farmakoterapiï koronavirusnoï hvorobi (COVID-19) u pacientiv z dual'nimi rozladami. Informacijnij list pro novovvedennya Ukrmedpatentinform MOZ Ukraïni. - K.: Ukrmedpatentinform MOZ Ukraïni. - 2020. - № 230-2020. - 6 p.

4. GajduchokI. G., Shapovalova V. O., Shapovalov V. V., Shapovalov V. V. Rezhim kontrolyu likars'kih zasobiv dlya farmakoterapiï koronavirusnoï hvorobi (COVID-19) u hvorih na sistemni zahvoryuvannya. Informacijnij list pro novovvedennya Ukrmedpatentinform MOZ Ukraïni. - K.: Ukrmedpatentinform MOZ Ukraïni. - 2020. № 225-2020. - 6 p.

5. GajduchokI. G., Shapovalova V. O., Shapovalov (Mol.) V. V., Shapovalov V. V. Rezhim kontrolyu likars'kih zasobiv dlya farmakoterapiï vaskulitu Shenlejn - Genoha: Informacijnij list pro novovvedennya Ukrmedpatentinform MOZ Ukraïni. K.: Ukrmedpatentinform MOZ Ukraïni, 2021. - № 64-2021. - 7 p.

6. Gudzenko A.O, Osinceva A.O., Shapovalova V.O. ta in. Kontent-analiz obigu spirtovih likars'kih zasobiv za likars'koyu formoyu ta reestracijnimi posvidchennyami. - Avtors'ke pravo 79473 (Ukraïna). - Zayavka № 80713 vid 24.05.2018. Opubl. 01.06.18.

7. Emchenko Ya. O., Ishchejkin K. C., Kajdashev I. P. Analiz zahvoryuvanosti ta poshirenosti na psoriaz v Ukraïni ta v Poltavs'kij oblasti. - Visnik VDNZU «Ukraïns'ka medichna stomatologichna akademiya». - 2014. - T. 14, Vip. 3. - P. 72-76.

8. Shapovalova V.O., Zbrozhek S.I., Shapovalov (Mol.) V. V., Shapovalov V. V. Kontent-analiz aptechnih zakladiv Ukraïni, de vigotovlyayut' ekstemporal'ni likars'ki zasobi // Zdorov'ya suspil'stva. - 2017. T. 6, № 3-4. - P. 77-83. - DOI: 10.22141/2306-2436.6.3.2017.123498

9. Anderson P. D., O'Donnell J. The Forensic Pharmacist. Drug Injury: Liability, Analysis, and Prevention // Hardcover. - 2017. - Vol. 23. - P. 761-770.

10. Beketova T. V., Blank L. M., Lila A. M. COVID-19 in a patient with ANCA-associated systemic vasculitis, receiving anti-B cell therapy (rituximab)// Rheumatology Science and Practice. - 2019. [Internet]. https://rsp.mediar-press.net/rsp/article/view/2889?locale=ru_RU\#

11. Christy J., Ledford W. Content Analysis of Internet Marketing Strategies: How Pharmaceutical Companies Communicate about Contraceptives with Consumers Online // J. Med. Internet Res. - 2009. - https://journals.sagepub.com/doi/abs/10.1080/15245000903038308

12. Davis J. Content analysis of efficacy descriptions on branded pharmaceutical websites // J. of Med. Marketing. - 2012. - Vol. 12, N. 4. - P. 211-220. - DOI:10.1177/1745790412465425

13. Gudzenko A. Experience of Finland in the field of pharmaceutical provision of certain categories of the population // Actual problems of medicine and pharmacy. - 2020. - Vol. 1, N. 1-2. - https://apmplmi.com 
14. Hayduchok I. Pharmacotherapy of Systemic Vasculitis Combined with Cryoglobulinemic Syndrome using Pharmacoeconomic Approaches // Global J. of Health Science. - 2021. - Vol. 13, N. 7. - P. 78-88. DOI: 10.5539/gjhs.v13n7p78.- https://doi.org/10.5539/gjhs.v13n7p78

15. Hayduchok I. Pharmacotherapy of immunopathological syndromes among patients with systemic lupus erythematosus based on ABC/VEN analysis // Acta Scientific Medical Science. 2021. - Vol. 5, Iss. 6. - P. 67-73. - DOI: 10.31080/ASMS 2020.05.0925

16. Hayduchok I., Shapovalov V. Organizational and legal measures of state control of reforming and modernizing the health care on principles of pharmaceutical and medical law // Actual problems of medicine and pharmacy. - 2020. - Vol. 1, N. 1-2. - https://apmplmi.com

17. Management Science for Health. - Managing Medicines Selection. - Managing Access to Medicines and Health Technologies. - USA: Arlington, 2012. - P. 16.1-16.15.

18. Parnes O. Autoimmune disease // The Lancet. - 2018. - Vol. 367. - P. 389.

19. Shapovalov (Jr.) V., Gudzenko A., Komar L. et al. Concerning the importance of forensic and pharmaceutical researches to improve patients' accessibility to medicines // Pharmacia. 2017. - Vol. 65, N. 2. - P. 23-29.

20. Shapovalov (Jr.) V., Gudzenko A., Shapovalova V. et al. Forensic and pharmaceutical study of the presence of a causal link between the degree of alcohol abuse and qualification level of the respondents // Pharmacia. - 2017. - Vol. 66, N. 3. - P. 31-39.

21. Shapovalov (Jr.) V, Zbrozhek S., Gudzenko A. et al. Organizational and legal analysis of the pharmaceutical provision for the most common diseases of society // International Journal of Pharmaceutical Sciences Review and Research. - 2018. - Vol. 51, N. 18. - P. 118-124.

22. Shapovalova $V$. System of drugs circulation based on medical and pharmaceutical law // Actual problem of medicine and pharmacy. - 2020. - Vol. 1, N. 1-2. - http://apmplmi.com

23. Shapovalova V. O., Zbrozhek S. I., Shapovalov (Jr.) V. V., Shapovalov V. V. Coronavirus disease pandemia 2019: growth of epidemic dangers // Acta scientific pharmaceutical sciences. -2020 . - Vol. 4, N. 7. - P. 61-68.

24. Shapovalova V. A., Zbrozhek S. I., Shapovalov V. V, Shapovalov V. V. Forensic pharmacy: some risk factors in the formation of addictive health disorders // Acta Scientific Pharmaceutical Science. - 2021. - Vol. 4, N. 1. - P. 7-12. - DOI: 10.3180 / ASPS.2020.05.0651

25. Shapovalova V. A., Zbrozhek S. I., Shapovalov V. V, Shapovalov V. V. Organizational and legal evaluation of availability of medicines' circulation for cancer patients // Pharmacia. 2018. - Vol. 65, N. 2. - P. 17-22.

26. Shapovalov V. V. (Jr.), Gudzenko A. O., Shapovalova V. A. et al. Experience of Poland concerning and organization of healthcare system for the pharmaceutical provision for privileged categories of citizens. - A Czech Republic, Karlovy Vary: Skleněný Můstek - Kyiv: MCNIP, 2019. - P. 16-22.

27. Shapovalov $V$. Use of innovative technologies in pharmacotherapy with target nanotherapy on the principles of evidence-based medicine and pharmacy // Actual problem of medicine and pharmacy. - 2020. - Vol. 1, N 1-2. - http://apmplmi.com

28. Takakubo K., Konttinen $Y$. Immune-regulatory mechanisms in systemic autoimmune and rheumatic diseases // Clin. Dev. Immunol. - 2012. - Vol. 37, N. 3. - P. 341-346.

\section{ІННОВАЦІЙНІ ПІДХОДИ ДО ФАРМАКОТЕРАПІЇ СИСТЕМНИХ АУТОІМУННИХ ХВОРОБ В УМОВАХ ПАНДЕМІЇ COVID-19}

\section{I. Г. Гайдучок (Львів)}

Вступ. В сучасних умовах поширення коронавірусної пандемії зростає роль фармакотерапії супроводу імунопатологічних синдромів у хворих на системні хвороби та пацієнтів 3 дуальними розладами здоров'я. Необхідність корекції схем фармакотерапії системних аутоімунних хвороб з'являється при вирішенні питань щодо якості, економічної та фізичної доступності лікарських засобів у відповідності до оптово-роздрібних цін. В продовження досліджень метою роботи стало вивчення та впровадження інноваційних підходів у фармакотерапію системних аутоімунних хвороб шляхом контентного аналізу на прикладі противірусних препаратів за Міжнародною непатентованою назвою (МНH) ацикловір. Матеріали та методи. Інформаційну базу дослідження склали наукові праці іноземних та вітчизняних вчених за темою статті. Огляд наукових джерел літератури було проведено із врахуванням рекомендацій Кокрейнівського товариства за РІСО. Найменування лікарських препаратів були систематизовані за МНH, торговельними назвами, за кількістю лікарських препаратів, лікарських форм. Для проведення контентного аналізу було використано роз- 
роблену кафедрою медичного та фармацевтичного права, загальної і клінічної фармації Харківської медичної академії післядипломної освіти методику відбору лікарських засобів (ЛЗ), яка включала сім критеріїв. Обговорення. На першому етапі дослідження було проведено маркетинговий аналіз асортименту ЛЗ за МНН ацикловір. Обрано ЛЗ, які, за даними Державного реєстру ЛЗ України станом на листопад 2020 р., були зареєстровані та дозволені до обігу в закладах охорони здоров'я. Після узагальнення опрацьованих даних було складено маркетинговий перелік Л3 за АТС кодом Ј05АВ01 відповідно до МНН ацикловір, який налічує 36 найменувань ЛЗ. Під час проведення дослідження складено дискретний варіаційний ряд розподілення ЛЗ, який вказує на те, що досліджуваний кількісний показник виробників Л3 коливається в межах першої групи з найвищою частотою $\left(f_{\mathrm{i}}=8\right)$. Створено графічний дискретний варіаційний у вигляді полігону розподілення. Висновки. Інноваційні підході до фармакотерапії системних аутоімунних хвороб полягають в застосуванні контент-аналізу в якості додаткового методу у вивченні забезпечення фармакотерапії ЛЗ. Вивчення відбувається з позиції формалізованого методу якісного та кількісного аналізу документів, що дозволяє отримати детальне уявлення про обраної клініко-фармакологічної групи ЛЗ - ЛЗ за INN aciclovir (ATC-код J05AB01). Проведений аналіз дозволяє отримати повну характеристику асортименту і виробників препаратів, дозволених до застосування.

Ключові слова: доказова медицина; судова фармація; фармакотерапія; системні аутоімунні хвороби; лікарські засоби; контент-аналіз.

\section{ИННОВАЦИОННЫЕ ПОДХОДЫ К ФАРМАКОТЕРАПИИ СИСТЕМНЫХ АУТОИММУННЫХ БОЛЕЗНЕЙ В УСЛОВИЯХ ПАНДЕМИИ COVID-19}

\section{И. Г. Гайдучок (Львов)}

Введение. В современных условиях распространения коронавирусной пандемии возрастает роль фармакотерапии сопровождения иммунопатологических синдромов у больных с системными заболеваниями и больных с дуальными расстройствами здоровья. Необходимость коррекции схем фармакотерапии системных аутоиммунных заболеваний появляется при решении вопросов качества, экономической и физической доступности лекарственных средств (ЛС) в соответствии с оптово-розничными ценами. Целью работы стало изучение и внедрение инновационных подходов в фармакотерапии системных аутоиммунных болезней путём контентного анализа на примере противовирусного препарата по Международному непатентованному названию (МНН) ацикловир. Материалы и методы. Информационную базу исследования составили научные труды зарубежных и отечественных учёных по теме статьи. Обзор научных источников литературы был проведён с учётом рекомендаций Кокрейновского общества по РІСО. Наименование ЛС были систематизированы по МНH, торговым названиям, по количеству ЛС, лекарственной формы. Для проведения контентного анализа была использована разработанная кафедрой медицинского и фармацевтического права, общей и клинической фармации Харьковской медицинской академии последипломного образования методика отбора ЛС, которая включала семь критериев. Обсуждение. На первом этапе исследования был проведён маркетинговый анализ ассортимента ЛС по МНН ацикловир. Отобраны ЛС, которые, по данным Государственного реестра лекарственных средств Украины по состоянию на ноябрь 2020 г., были зарегистрированы и разрешены к применению в учреждениях здравоохранения. После обобщения обработанных данных был составлен маркетинговый перечень ЛС по АТС коду Ј05АВ01 в соответствии с МНН ацикловир, который насчитывает 36 наименований ЛС. Во время проведения исследования составлен дискретный вариационный ряд распределения ЛС, указывающий на то, что исследуемый количественный показатель производителей ЛС колеблется в пределах первой группы с наивысшей частотой $\left(f_{\mathrm{i}}=8\right)$. Построен графический дискретный вариационный в виде полигона распределения. Выводы. Инновационные подходы к фармакотерапии системных аутоиммунных болезней заключаются в применении контент-анализа в качестве дополнительного метода в изучении обеспечения фармакотерапии ЛС. Изучение происходит с позиции формализованного метода качественного и количественного анализа документов, позволяет получить детальное представление о выбранной клинико-фармакологической группе ЛС - ЛС по МНН ацикловир (ATC-код J05AB01). Проведённый анализ позволяет получить полную характеристику ассортимента и производителей препаратов, разрешённых к применению.

Ключевые слова: доказательная медицина; судебная фармация; фармакотерапия; системные аутоиммунные болезни; лекарственные средства; контент-анализ. 